\title{
Испытание сортов картофеля в условиях Астраханской области
}

\section{Т.В. Боева, Ш.Б. Байрамбеков, А.С. Соколов}

Для почвенно-климатических условий Астраханской области были выделены перспективные, с высокой товарностью сорта картофеля, обладающие высокой урожайностью, потребительскими качествами и представляющие интерес для с.-х. товаропроизводителей и дальнейшей научной работы: Гулливер, Лига, Ред Скарлетт, Джувел, Импала, Аксения, Удача и Ред Соня.

Ключевые слова: картофель, Solanum tuberosum, сорт, продуктивность, качество, рентабельность.

артофель - один из основных продуктов питания чело-

века, который по объему производства занимает второе место в мире после зерновых культур. По посевным площадям и валовым сборам этой культуры Россия уступает только Китаю. В Астраханской области четко прослеживается тенденция к увеличению площадей под картофелем, и особенно под посадками раннего картофеля [1]. В 2018 году из общей площади в 11 тыс. га, на 7 тыс. га выращивали ранний картофель. Благодаря орошению и правильно подобранным сортам, средняя урожайность по области составила 29,5 т/га, что выше средней по стране. Передовые хозяйства стабильно получают 40-45 т/га. Область стала вывозящей, более 130 тыс. т реализуют за ее пределами. Дальнейшее развитие картофелеводства должно строиться прежде всего на основе перспективных сортов и качественном семенном материале [2]. Сорт позволяет совершенствовать с.- х. производство и повышать его рентабельность за счет высокой урожайности, товарности и качества продукции. Причем, эффективную отдачу от сорта можно получить только при возделывании в оптимальных почвенно-климатических условиях, наиболее отвечающих его генотипическим особенностям [3].

Цель наших исследований заключалась в оценке сортов картофеля отечественной и зарубежной селекции в специфических условиях Астраханской области.

Исследования проводили в 20172018 годах в Харабалинском районе Астраханской области в КФХ

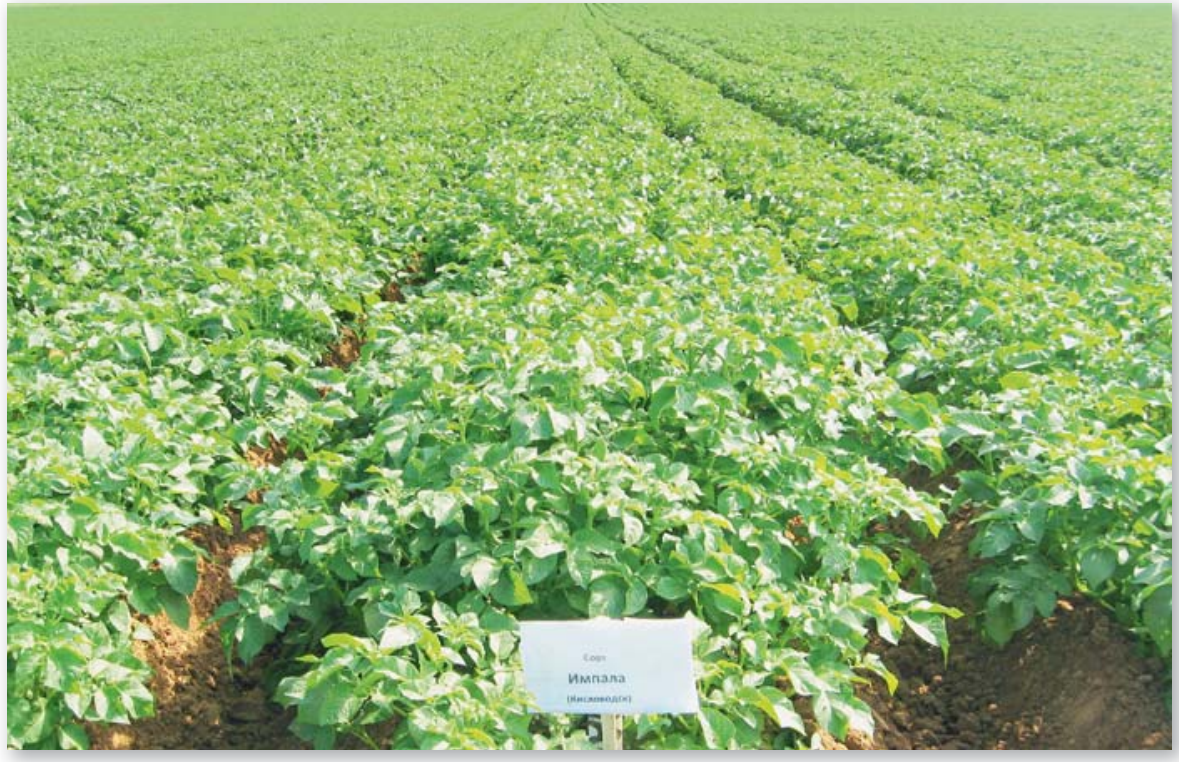

Рис. 1. Сорт картофеля Импала
«А.В. Крынина». Опыты закладывали методом расщепленных делянок. Общая площадь делянки - 50 м²,

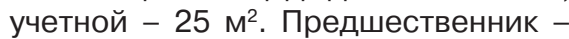
залежь. Для посадки в первой декаде апреля использовали клубни картофеля элиты, произведенные в Московской и Костромской областях, г.Кисловодске, а также Северной Осетии. Клубни всех сортов картофеля проходили яровизацию в течение трех недель при температуре +16-18 ${ }^{\circ} \mathrm{C}$. Агротехника возделывания общепринятая в регионе, согласно рекомендациям по Астраханской технологии производства картофеля [4]. Уборку и учет урожая проводили во второй декаде июня. Работу выполняли в соответствии со стандартными селекционными методиками [5, 6, 7, 8].

Почвы опытных участков Харабалинского района по гранулометрическому составу легкосуглинистые. Содержание легкогидролизуемого азота в слое 0,0-0,4 м было низким и составляло по годам исследований 58,4-61,2 мг/кг. Содержание подвижных форм фосфора в этом горизонте изменялось от 63,1 до 67,9 мг/кг, обменного калия - от 198,1 до 220,5 мг/Кг, что соответствовало средней обеспеченности. Содержание гумуса в почве - 1,63-1,87\%.

Полив проводили капельным способом. Оросительная норма за сезон составляла 2800 м³$^{3} /$ га. В опытах поддерживали полевую влагоемкость на уровне 80-85\% от НВ. Сумма эффективных температур, полученная растениями картофеля, $-1226{ }^{\circ} \mathrm{C}$.

Урожайность - важный оценочный критерий при испытании сортов. Анализ данных урожайности различных сортов картофеля показал, что 4 образца - Гулливер $(51,4$ т/га), Лига и Ред Скарлетт (49,6 т/ га), Джувел (48,1 т/га) превысили по этому показателю стандартный сорт Импала $(47,7$ т/га). Незначительно на 0,3-1,8 т/га уступили стандарту сорта Аксения, Удача, Ред Соня и Серафина. Высокая товарность $98 \%$, на уровне стандартного сорта Импала (рис. 1), отмечена у сор- 
тов Гулливер (рис. 2), Лига, Ред Скарлетт, Аксения, Серафина. У сортов Латона (42,9 т/га), Вымпел $(40,7$ т/га), Фаворит (40,7 т/га) также выявлена высокая товарность клубней 94\%, хотя урожайность данных сортообразцов ниже стандарта на 4,87,0 т/га. У изучаемых сортов Краса Мещеры, Нандина, Вершининский, Терра, Бельмондо и Люкс урожайность составила от 36,2 до 38,8 т/га, товарность продукции - 68-84\%, что на 14-30\% ниже аналогичного показателя у стандартного сорта Импала (табл. 1).

В наших исследованиях подтверждена общая закономерность динамики биохимического состава клубней, свойственная группе ранних сортов картофеля. По содержанию сухого вещества выделились сорта Гулливер, Ред Соня, Аксения, Серафина, Ред Скарлетт, Кристель,

Таблица 1. Продуктивность сортообразцов картофеля в коллекционном питомнике (среднее 2017-2018 годы)

\begin{tabular}{|c|c|c|c|c|}
\hline $\begin{array}{l}\text { Название } \\
\text { образца }\end{array}$ & $\begin{array}{l}\text { Количество } \\
\text { клубней, шт. }\end{array}$ & $\begin{array}{c}\text { Масса клубней } \\
\text { с одного } \\
\text { растения, кг }\end{array}$ & $\begin{array}{c}\text { Урожайность, } \\
\text { т/га }\end{array}$ & Товарность, \% \\
\hline Импала (st.) & 10,6 & 1,29 & 47,7 & 98 \\
\hline Гулливер & 8,7 & 1,39 & 51,4 & 98 \\
\hline Лига & 10,3 & 1,30 & 49,6 & 98 \\
\hline Ред Скарлетт & 11.0 & 1,34 & 49,6 & 98 \\
\hline Джувел & 15,0 & 1,30 & 48,1 & 95 \\
\hline Аксения & 12,1 & 1,28 & 47,4 & 98 \\
\hline Удача & 9,8 & 1,26 & 46,6 & 96 \\
\hline Ред Соня & 11,0 & 1,25 & 46,3 & 94 \\
\hline Романо & 9,8 & 1,25 & 46,3 & 96 \\
\hline Серафина & 11,1 & 1,24 & 45,9 & 98 \\
\hline Кроне & 15,2 & 1,22 & 45,1 & 91 \\
\hline Мечта & 13,0 & 1,20 & 44,4 & 89 \\
\hline Лисана & 13,1 & 1,20 & 44,4 & 81 \\
\hline Латона & 9,2 & 1,16 & 42,9 & 94 \\
\hline Фаворит & 13,6 & 1,10 & 40,7 & 94 \\
\hline Вымпел & 10,6 & 1,11 & 40,7 & 94 \\
\hline Навигатор & 10,3 & 1,10 & 40,7 & 92 \\
\hline Кристель & 9,8 & 1,10 & 40,7 & 91 \\
\hline Лаперла & 13,0 & 1,10 & 40,7 & 87 \\
\hline Мишка & 13,4 & 1,10 & 40,7 & 86 \\
\hline Капри & 8,7 & 1,08 & 40,0 & 92 \\
\hline Нандина & 11,8 & 1,05 & 38,9 & 78 \\
\hline Люкс & 12,3 & 1,05 & 38,8 & 84 \\
\hline Бельмонда & 12,0 & 1,04 & 38,5 & 82 \\
\hline Вершининский & 12,0 & 1,00 & 37,0 & 79 \\
\hline Краса Мещеры & 12,0 & 1,00 & 37,0 & 68 \\
\hline Teppa & 11,0 & 0,98 & 36,2 & 82 \\
\hline $\mathrm{HCP}_{05}$ & 1,7 & F申. < FT. & 1,4 & - \\
\hline
\end{tabular}

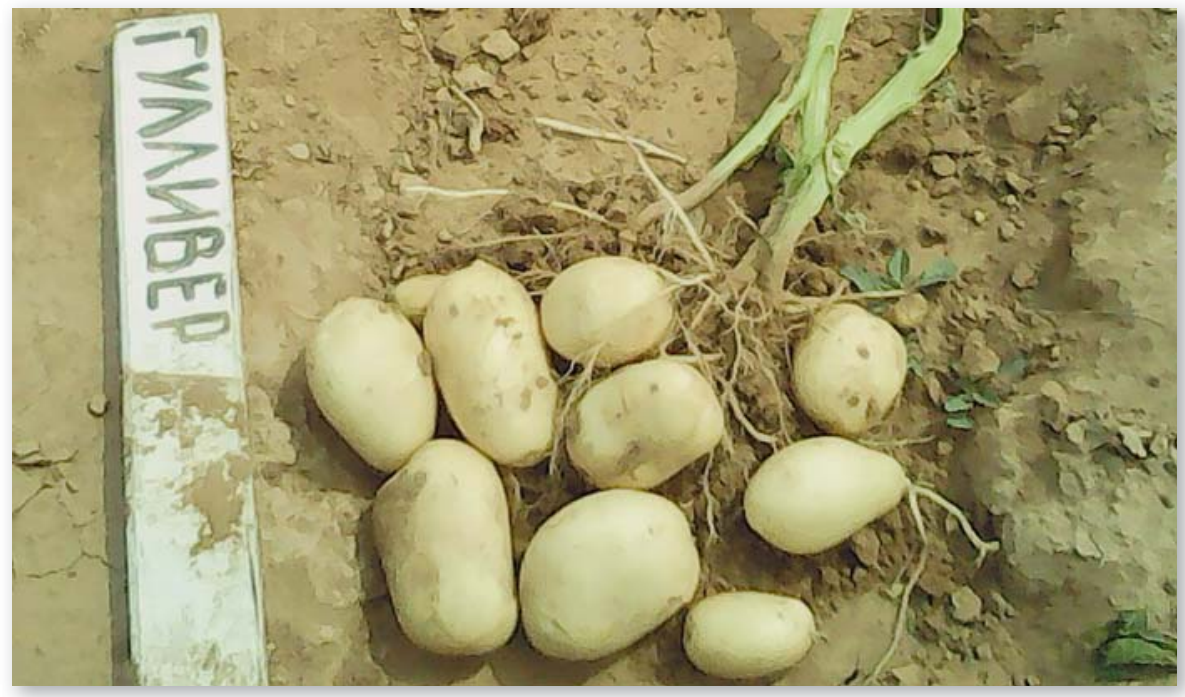

Рис. 2. Сорт картофеля Гулливер (пробная копка)
Лига, Удача, Мечта, Навигатор (20,86-21,47\%), превысившие стандартный сорт Импала на 0,78-1,39\%. Наибольшее содержание сахаров $(0,74-0,87 \%)$ выявлено у сортов Ред Скарлетт, Ред Соня, Люкс, Аксения, Гулливер, Удача, Навигатор, причем этот показатель на 0,01-0,14\% выше, чем у стандартного сорта Импала. У сортов Капри, Гулливер, Джувел, Кроне, Мишка, Люкс, Ред Скарлетт, Фаворит, Навигатор, Вымпел, Серафина, Лига установлено повышенное содержание крахмала на 0,2-2,9\%, в сравнении со стандартом (13,9\%). По содержанию аскорбиновой кислоты выделились сорта Нандина, Капри Гулливер, Джувел, Кроне, Ред Соня, Люкс, Аксения, Лига, Удача, Вымпел (17,118,8 мг/\%). В условиях Астраханской области сорта Гулливер, Ред Соня, Ред Скарлетт, Аксения, Джувел, Лига, Удача, Навигатор и Вымпел способны накапливать повышенное, по сравнению со стандартом, количество сухого вещества, сахаров, крахмала и аскорбиновой кислоты (табл. 2).

Экономическую оценку проводили с использованием следующих показателей: урожайность, производственные затраты, рентабельность. Производственные затраты определялись согласно технологической карты. В производственные затраты также включены: стоимость ГСМ, капельного оборудования и его обслуживание, подача воды для орошения, стоимость посадочного материала (клубней картофеля), минеральных удобрений. Расчет экономической эффективности пока- 
зал, что возделывание картофеля в условиях Астраханской области рентабельно и экономически выгодно при урожайности свыше 30 т/га. Наибольшая урожайность получена у сортов Гулливер, Лига, Ред Скарлетт, Джувел, Импала, Аксения, Удача. Рентабельность при их возделывании составила 187,7\%, 177,6\%, $169,3 \%$, 167,0\%, 165,0\%, 160,9\% соответственно.

Агроэкологическая оценка позволила определить затраты совокупной энергии при выращивании картофеля, которая в наших опытах составила 52480 МДж/га. Энергоемкость 1 т картофеля на всех сортах составила 3142 МДж/т. Наибольший показатель значения энергии урожая отмечен у сортов Гулливер (161500 МДж/ га), Лига и Ред Скарлетт (155843 МДж/га), Импала (149873 МДж/га), Удача (146417 МДж/га). Наименьшее значение энергии урожая отмече- ны у сортов Терра (113740 МДж/ га), Вершининский, Краса Мещеры (116254 МДж/га). Наибольшее значение коэффициента энергетической эффективности было у сорта Гулливер - 3,08, у сортов Лига и Ред Скарлетт оно составило 2,97. Сорта Терра $(2,16)$, Краса Мещеры Вершининский, Бельмонда по этому показателю значительно уступили стандарту сорту Импала $(2,86)$.

Таким образом, для почвенно-климатических условиях Астраханской области были выделены перспективные, урожайные, с высокой товарностью сорта картофеля Гулливер, Лига, Ред Скарлетт, Джувел, Импала, Аксения, Удача, Ред Соня.

\section{Библиографический список} 1.Боева Т.В., Байрамбеков Ш.Б., Дубровин Н.К. Перспективы развития картофелеводства в Астраханской области // Элементы технологии возделывания сельскохозяйственных культур в услови-

Таблица 2. Биохимический анализ клубней различных сортов картофеля в коллекционном питомнике (среднее 2017-2018 годы)

\begin{tabular}{|c|c|c|c|c|}
\hline \multirow{2}{*}{$\begin{array}{l}\text { Название } \\
\text { образца }\end{array}$} & \multicolumn{3}{|c|}{ В \% на сырое вещество } & \multirow{2}{*}{$\begin{array}{l}\text { Аскорбиновая } \\
\text { кислота, мг/\% }\end{array}$} \\
\hline & $\begin{array}{c}\text { сухого } \\
\text { вещества }\end{array}$ & сумма сахаров & крахмала & \\
\hline Импала (st.) & 20,08 & 0,73 & 13,9 & 16,59 \\
\hline Гулливер & 21,05 & 0,75 & 14,8 & 18,80 \\
\hline Лига & 20,77 & 0,86 & 14,2 & 17,67 \\
\hline Ред Скарлетт & 20,88 & 0,87 & 14,6 & 16,97 \\
\hline Джувел & 19,78 & 0,57 & 14,9 & 18,40 \\
\hline Аксения & 23,10 & 0,78 & 12,8 & 17,16 \\
\hline Удача & 20,86 & 0,74 & 13,9 & 17,32 \\
\hline Ред Соня & 21,10 & 0,78 & 13,5 & 18,00 \\
\hline Романо & 19,05 & 0,72 & 12,5 & 15,89 \\
\hline Серафина & 22,80 & 0,76 & 14,7 & 15,59 \\
\hline Кроне & 15,96 & 0,72 & 14,3 & 17,10 \\
\hline Мечта & 21,13 & 0,72 & 13,5 & 15,96 \\
\hline Лисана & 15,66 & 0,48 & 13,8 & 16,98 \\
\hline Латона & 17,24 & 0,58 & 13,9 & 16,71 \\
\hline Фаворит & 19,88 & 0,67 & 14,1 & 16,58 \\
\hline Вымпел & 19,63 & 0,65 & 16,8 & 17,61 \\
\hline Навигатор & 21,47 & 0,76 & 14,9 & 16,20 \\
\hline Кристель & 20,36 & 0,62 & 13,3 & 14.13 \\
\hline Лаперла & 17,11 & 0,69 & 12,9 & 15,80 \\
\hline Мишка & 18,30 & 0,70 & 15,8 & 16,70 \\
\hline Капри & 19,23 & 0,53 & 16,2 & 17,60 \\
\hline Нандина & 17,24 & 0,61 & 13,7 & 17,10 \\
\hline Люкс & 19,40 & 0,81 & 14,1 & 17,89 \\
\hline Бельмонда & 17,30 & 0,59 & 13,7 & 16,80 \\
\hline Вершининский & 18,78 & 0,61 & 13,6 & 16,31 \\
\hline Краса Мещеры & 17,96 & 0,59 & 12,7 & 15,09 \\
\hline Teppa & 18,15 & 0,73 & 13,8 & 15,78 \\
\hline
\end{tabular}

ях орошения: сборник трудов Междунар. науч.-практ. конф. (Астрахань, 28-29 апреля 2016 г.). Астрахань: Изд. Сорокин Р.В., 2016. С. 29-32.

2.Серегина Н.И. Сорт, качество, технология - факторы высокой урожайности картофеля // Картофель и овощи. 2012. № 6. С. 7-8.

3.Симаков Е.А. и др. Сорта картофеля, возделываемые в России. М.: КолосС, 2005. 110 с.

4.Байрамбеков Ш.Б. и др. Технология производства картофеля в Астраханской области: рекомендации. Астрахань: Издатель Сорокин Р.В., 2013. 100 с.

5.Белик В.Ф. Методика опытного дела в овощеводстве и бахчеводстве. М.: Агропромиздат, 1992. 319 с.

6 Доспехов Б.А. Методика полевого опыта. М.: Колос, 1973. $336 \mathrm{c}$

7.Методические указания по технологии селекционного процесса картофеля. М.: ВНИИКХ им. А.Г. Лорха, 2006. 22 c.

8.Технологический процесс производства оригинального, элитного и репродукционного семенного картофеля: методические рекомендации. М.: ФГБУ «Россельхозцентр», ГНУ ВНИИКХ, 2011. 32 с.

\section{Об авторах}

Боева Тамара Васильевна, канд. с. -х. наук, с.н.с. отдела агротехнологий и мелиораций

Байрамбеков Шамиль Байрамбекович, доктор с.-х. наук, профессор, зав. отделом агротехнологий и мелиораций Соколов Артем Сергеевич, С.н.С. отдела селекции и семеноводства Всероссийский научно-исследовательский институт орошаемого овощеводства и бахчеводства - филиал ФГБНУ «Прикаспийский аграрный федеральный научный центр Российской академии наук». E-mail: vniiob@mail.ru

Probation of potato varieties in the Astrakhan region

T.V. Boeva, $P h D$, senior research fellow,

Department of agronomy and land

reclamation

Sh.B. Bairambekov, DSc, prof., head of the Department of agricultural technologies and land reclamation

A.S. Sokolov, senior research fellow of the Department of selection and seed production

All-Russian research Institute of irrigated vegetable and melon growing - the branch of FSBI «Near-Caspian Federal agricultural research center, Russian Academy of Sciences» (ARRIIVMG - branch FSBI «NCFARC RAS. E-mail: vniiob@mail.ru

Summary. For soil and climatic conditions of the Astrakhan region were identified promising, with high marketability potato varieties with high yields, consumer qualities and of interest to agricultural producers and further research: Gulliver, League, Red Scarlett, Jewel, Impala, Aksenia, Udacha and Red Sonya.

Keywords: potato, Solanum tuberosum, variety, productivity, quality, profitability. 